\title{
Relationship Between Plasma Insulin Levels and High Density Lipoprotein Cholesterol Levels in Healthy Men
}

\author{
M. Stalder, D. Pometta and A. Suenram \\ Division de Diabetologie, Hôpital Cantonal Universitaire, Geneva, Switzerland
}

Summary. Insulin and high density lipoproteins are considered to play a role in the development of atherosclerosis. In order to study whether there was a relationship between endogenous plasma insulin response and high density lipoproteins, an acute intravenous glucose tolerance test $(0.5 \mathrm{~g}$ glucose $/ \mathrm{kg}$ body weight) was performed in 94 healthy men, aged $20-49$ years. Cholesterol and triglyceride levels were measured in very low density lipoproteins, low density lipoproteins and high density lipoproteins isolated from fasting serum by preparative ultracentrifugation. The subjects were divided into quartiles according to their fasting and post-glucose load plasma insulin and high density lipoprotein cholesterol levels. The results obtained in the subjects of the upper quartiles were compared with the results obtained in the subjects of the lower quartiles. The mean glucose disappearance rates were within the normal range and did not differ between the upper and lower quartiles. Subjects with high fasting plasma insulin had lower high density lipoprotein cholesterol levels (1.11 \pm $0.34 \mathrm{mmol} / 1, p=0.01$ ) than men with low fasting plasma insulin $(1.40 \pm 0.37 \mathrm{mmol} / 1)$. Higher mean post-glucose plasma insulin was associated with lower high density lipoprotein cholesterol levels (1.18 \pm $0.32 \mathrm{mmol} / 1, p<0.05$ ) and increased high density lipoprotein triglyceride levels $(0.14 \pm 0.07 \mathrm{mmol} / \mathrm{l}$, $p<0.01)$ when compared with the men with low post-glucose plasma insulin $(1.40 \pm 0.36 \mathrm{mmol} / 1$ and $0.09 \pm 0.03 \mathrm{mmol} / 1$ respectively). These observations reflect the close relationship between endogenous insulin and lipoprotein metabolism.

Key words: Plasma insulin, lipoproteins, HDL cholesterol, intravenous glucose tolerance test.

Low high density lipoprotein (HDL) cholesterol is associated with coronary heart disease $[1-7]$ and has a better predictive value for the occurrence of myocardial infarction than low density lipoprotein (LDL) cholesterol $[5,6]$. The 'favourable effect' of HDL cho- lesterol has been related to tissue cholesterol transport and competitive action at the LDL surface cell receptors [8-10]. In previous studies, we demonstrated that the first degree relatives of patients who have had acute myocardial infarction had lower HDL cholesterol than control subjects $[11,12]$ and that low HDL cholesterol was demonstrable even in children [13].

The prevalence of hyperlipoproteinaemia and coronary heart disease is high among diabetics but is not related to the severity of diabetes measured by the degree of insulin dependence [14-17]; indeed, latent diabetics may have severe cardiovascular disease [18]. Overt diabetics, both insulin dependent or independent, have been shown to have low HDL cholesterol [19-22], which could possibly be considered as a cardiovascular risk factor. During insulin therapy, a rise in HDL cholesterol has been observed [23], suggesting that improved diabetic control may decrease the risk of ischaemic heart disease [24]. Contradictory results have been found by others $[25,26]$.

The purpose of the present study was to investigate whether in a healthy population there was a relationship between HDL cholesterol and endogenous plasma insulin. The subjects were divided into quartiles on the basis of fasting insulin, insulin after an intravenous glucose challenge and HDL cholesterol. Comparisons were made between the subjects of the upper and lower quartiles with special attention to the lipoprotein, cholesterol and triglyceride levels.

\section{Subjects and Methods}

The subjects of the present study were men (aged 20-49 years) randomly selected from an apparently healthy population who participated in Geneva in the study 'Serum lipoproteins in four European communities' [27]. The following predetermined grounds for exclusion were employed to define the healthy population: (a) Clinical and ECG evidence of ischaemic heart disease, and evidence of peripheral vascular disease from history and clinical examination. (b) Known diabetes mellitus or fasting plasma glucose ( $\geqslant 8.0 \mathrm{mmol} / \mathrm{l})$ [18]. (c) Cirrhosis of the liver, chronic renal failure, and malignant disease. (d) Adherence to therapeutic diets (e. g. weight-reducing or diabetic diets), the taking of drugs known to affect lipid or carbohy- 
Table 1. Comparison between subjects selected according to the fasting insulin quartiles

\begin{tabular}{|c|c|c|c|c|}
\hline & \multicolumn{4}{|c|}{ Fasting insulin (IRI) } \\
\hline & $\begin{array}{l}\text { Quartile I } \\
(1-6.9 \mathrm{mU} / \mathrm{l})\end{array}$ & $\begin{array}{l}\text { Quartile II } \\
(7-10.9 \mathrm{mU} / 1)\end{array}$ & $\begin{array}{l}\text { Quartile III } \\
(11-17.9 \mathrm{mU} / 1)\end{array}$ & $\begin{array}{l}\text { Quartile IV } \\
(18-43 \mathrm{mU} / \mathrm{l})\end{array}$ \\
\hline Serum cholesterol $(\mathrm{mmol} / \mathrm{l})$ & $5.48 \pm 1.0$ & $5.34 \pm 0.94$ & $5.34 \pm 1.2$ & $5.53 \pm 1.17$ \\
\hline $\begin{array}{l}\text { Serum triglycerides }(\mathrm{log}) \\
\text { (antilog) }(\mathrm{mmol} / \mathrm{l})\end{array}$ & $\begin{array}{l}0.029 \pm 0.302 \\
1.07\end{array}$ & $\begin{array}{c}-0.045 \pm 0.173 \\
0.90\end{array}$ & $\begin{array}{c}-0.006 \pm 0.235 \\
0.98\end{array}$ & $\begin{array}{l}0.153 \pm 0.326 \\
1.42\end{array}$ \\
\hline HDL cholesterol $(\mathrm{mmol} / \mathrm{l})$ & ${ }^{\mathrm{a}} 1.40 \pm 0.37$ & $1.34 \pm 0.36$ & $1,24 \pm 0,32$ & $1.11 \pm 0.34$ \\
\hline HDL triglycerides (mmol/1) & $0.11 \pm 0.05$ & $0.11 \pm 0.05$ & $0.11 \pm 0.05$ & $0.14 \pm 0.07$ \\
\hline LDL cholesterol (mmol/l) & $3.07 \pm 0.68$ & $3.22 \pm 0.76$ & $3.25 \pm 0.89$ & $3.26 \pm 0.89$ \\
\hline $\begin{array}{l}\text { VLDL cholesterol (log) } \\
(\text { antilog) }(\mathrm{mmol} / \mathrm{l})\end{array}$ & $\begin{array}{c}-0.393 \pm 0.406 \\
0.40\end{array}$ & $\begin{array}{l}-0.464 \pm 0.217 \\
0.34\end{array}$ & $\begin{array}{l}-0.425 \pm 0.287 \\
0.38\end{array}$ & $\begin{array}{c}-0.274 \pm 0.373 \\
0.53\end{array}$ \\
\hline $\begin{array}{l}\text { VLDL triglycerides }(\mathrm{log}) \\
\text { (antilog) }(\mathrm{mmol} / \mathrm{l})\end{array}$ & $\begin{array}{l}-0.226 \pm 0.425 \\
0.59\end{array}$ & $\begin{array}{l}-0.314 \pm 0.248 \\
0.49\end{array}$ & $\begin{array}{c}-0.273 \pm 0.358 \\
0.53\end{array}$ & $\begin{array}{c}-0.069 \pm 0.419 \\
0.85\end{array}$ \\
\hline Fasting glucose $(\mathrm{mmol} / \mathrm{l})$ & $5.11 \pm 0.36$ & $5.07 \pm 0.52$ & $5.21 \pm 0.54$ & $5.34 \pm 0.86$ \\
\hline $\mathrm{K}(\% / \mathrm{min})$ & $1.60 \pm 0.51$ & $1.95 \pm 0.81$ & $1.68 \pm 0.43$ & $1.68 \pm 0.58$ \\
\hline Weight index & $0.97 \pm 0.09$ & $0.97 \pm 0.11$ & $1.01 \pm 0.13$ & $1.03 \pm 0.13$ \\
\hline
\end{tabular}

Results are expressed as mean \pm SD. K: disappearance rate of glucose $/ \mathrm{min}$. Comparison between quartiles I and IV: ${ }^{\mathrm{a}} p=0.01$

drate metabolism and a known change in body weight of more than $1.5 \mathrm{~kg}$ in the previous month. (e) Major acute illness, surgery or trauma within the previous 3 months.

Subjects attended the clinic on a weekday morning before work. Informed consent was obtained verbally from each subject before entering the study. The investigation included a medical history, physical examination and an ECG. Height and weight were recorded and the height/weight index derived:

weight $(\mathrm{kg})$

height $(\mathrm{cm})-100$

The subjects were asked to return to the clinic for an IV glucose tolerance test. They had been carefully instructed to eat at least $300 \mathrm{~g}$ of carbohydrates daily during the 3 days preceding the test and to fast for 12-14 $\mathrm{h}$ before the test. Venous blood was drawn in the fasting state for lipid analyses on whole serum and in the three major lipoprotein classes: VLDL, LDL and HDL. Cholesterol in whole serum and lipoproteins was measured after hydrolysis with ethanolic $\mathrm{KOH}$ and nonane extraction followed by the Liebermann-Burchard reaction [28]. Serum triglyceride levels were determined according to Soloni [29]. Lipoproteins were separated after preparative ultracentrifugation. The recovery and precision of the method were previously reported [11].

Plasma glucose was measured by enzymatic method (hexokinase) [30] and immunoreactive insulin (IRI) was measured using the Phadebas Pharmacia kit [31].

The IV glucose tolerance test was performed with $0.5 \mathrm{~g}$ glucose $(40 \%) / \mathrm{kg}$ body weight injected in less than $5 \mathrm{~min}$. The disappearance rate of glucose/ $\mathrm{min}(\mathrm{K})$ was determined graphically according to Amatuzio et al. [32]. Plasma glucose was determined before the test and after 10,20,30,40,50 and $60 \mathrm{~min}$. IRI measurements were made at $0,4,6,8,10,30$ and $60 \mathrm{~min}$ after the load in order to evaluate both the early and the late insulin secretion.

Alcohol consumption, cigarette smoking and physical activity were assessed by questioning during the medical examination. The alcohol consumption was expressed as litres of wine $\left(10^{\circ}\right)$ per week as the use of wine is more widespread than other alcohols in the Geneva area. Beers and hard liquors consumed were therefore transformed into wine 'equivalents' on the basis of pure alcohol content.

The statistical analysis of the differences between means of two samples was performed using the Student's ' $t$ ' test. Before calculation, serum and VLDL triglyceride levels as well as VLDL cholesterol were transformed to their logarithms. The Chi square test was used to compare the proportion of smokers, alcohol consumers and subjects with high or low physical activity both at work and at leisure between the samples studied.

\section{Results}

A total of 482 men entered the study, 14 of whom were excluded according to the predetermined grounds. One was an overt diabetic. From the remaining 468 men, 94 were randomly selected for the present study.

The results were analysed using quartiles defined according to insulin and to HDL cholesterol levels. The comparison was made between the lower (I) and upper (IV) quartiles but the results in the intermediate quartiles (Table 1) are consistent with the results of the lower and upper quartiles.

\section{Fasting Plasma Insulin}

Subjects with high fasting plasma insulin (quartile IV) had significantly lower HDL cholesterol (1.11 \pm $0.34 \mathrm{mmol} / 1$, mean $\pm \mathrm{SD}, p=0.01$ ) than subjects with low fasting insulin $(1.40 \pm 0.37 \mathrm{mmol} / \mathrm{l}$; Table 1). No differences could be found in fasting blood glucose or $\mathrm{K}$ values which were within normal range.

\section{Plasma Insulin After Glucose Load}

When the mean plasma insulin after glucose load was used to separate the low insulin responders (quartile $I$ ) and the high insulin responders (quartile IV) it appeared (Table 2) that high plasma insulin response was associated with low fasting HDL cholesterol $(1.18 \pm 0.32$ versus $1.40 \pm 0.36 \mathrm{mmol} / 1 ; p<0.05)$. High plasma insulin in response to glucose load was also associated with higher fasting HDL trigly- 
cerides $(0.14 \pm 0.07$ versus $0.09 \pm 0.03 \mathrm{mmol} / 1 ; p$ $<0.01)$ and increased body weight index $(1.04 \pm 0.13$ versus $0.95 \pm 0.10 ; p<0.05$ ).

There was no difference in the mean glucose or $\mathrm{K}$ values after the glucose challenge between the two quartiles.

\section{HDL Cholesterol and Plasma Insulin}

When the subjects were stratified according to their HDL cholesterol it appeared (Table 3) that low HDL cholesterol (quartile I) was associated with high plasma insulin both fasting $(16.6 \pm 11.0 \mathrm{mU} / \mathrm{l})$ and after glucose load $(41.5 \pm 20.9 \mathrm{mU} / 1, p<0.01)$. The subjects with high HDL cholesterol (quartile IV) had lower fasting IRI $(9.1 \pm 5.7 \mathrm{mU} / 1)$ and lower IRI after glucose load ( $27.1 \pm 14.4 \mathrm{mU} / 1, p=0.01)$.

Low HDL cholesterol was also associated with higher VLDL triglycerides ( 1.03 versus $0.35 \mathrm{mmol} / 1$, $p<0.001)$ and greater body weight index $(1.03 \pm 0.10$ versus $0.97 \pm 0.11, p<0.05$ ).

\section{Cigarette Smoking, Alcohol Consumption and Physical Activity}

No significant differences were found in cigarette smoking, alcohol consumption and physical activity either at work or at leisure between the quartiles under study.

\section{Description of the Population}

The mean values and standard deviations of the different variables studied for the entire population (94 men) are given in Table 4.

\section{Discussion}

From the present data, it appears that in contrast to previous observations by Enger and Erikssen [33] who found no correlation between fasting insulin and HDL cholesterol, the subjects with the highest fasting plasma insulin concentrations have lower HDL cholesterol when compared to subjects with lower fasting insulin who have higher HDL cholesterol.

High plasma insulin and low HDL cholesterol levels occur in obesity [5, 6, 34]. High fasting plasma insulin and low HDL cholesterol could therefore be related to obesity. However the mean body weight index of the group of subjects selected for their high fasting plasma insulin was within normal range and did not differ significantly from the body weight index of the subjects with low fasting insulin. The association of high fasting insulin and low HDL cholesterol is therefore not related to obesity.

When the plasma insulin levels measured after the glucose load are considered, it appears that similarly to what was observed at the fasting stage, the subjects
Table 2. Comparison between subjects with low (quartile I) and high (quartile IV) mean plasma insulin after IV glucose challenge

\begin{tabular}{|c|c|c|}
\hline & \multicolumn{2}{|c|}{$\begin{array}{l}\text { Mean plasma insulin (IRI) after } \\
\text { IV glucose }\end{array}$} \\
\hline & $\begin{array}{l}\text { Quartile I } \\
(9-21 \mathrm{mU} / 1)\end{array}$ & $\begin{array}{l}\text { Quartile IV } \\
(44-95 \mathrm{mU} / 1)\end{array}$ \\
\hline Serum cholesterol (mmol/l) & $5.35 \pm 0.80$ & $5.46 \pm 1.26$ \\
\hline $\begin{array}{l}\text { Serum triglycerides }(\mathrm{log}) \\
\quad(\text { antilog})(\mathrm{mmol} / \mathrm{l})\end{array}$ & $\begin{array}{c}-0.067 \pm 0.194 \\
0.86\end{array}$ & $\begin{array}{l}0.059 \pm 0.265 \\
1.15\end{array}$ \\
\hline HDL cholesterol $(\mathrm{mmol} / \mathrm{l})$ & ${ }^{\mathrm{a}} 1.40 \pm 0.36$ & $1.18 \pm 0.32$ \\
\hline HDL triglycerides (mmol/l) & ${ }^{b} 0.09 \pm 0.03$ & $0.14 \pm 0.07$ \\
\hline LDL cholesterol (mmol/1) & $3.21 \pm 0.63$ & $3.28 \pm 0.94$ \\
\hline $\begin{array}{l}\text { VLDL cholesterol (log) } \\
\text { (antilog) (mmol/1) }\end{array}$ & $\begin{array}{l}-0.535 \pm 0.267 \\
0.29\end{array}$ & $\begin{array}{l}-0.378 \pm 0.326 \\
\quad 0.42\end{array}$ \\
\hline $\begin{array}{l}\text { VLDL triglycerides (log) } \\
\text { (antilog) (mmol/1) }\end{array}$ & $\begin{array}{l}-0.354 \pm 0.315 \\
0.44\end{array}$ & $\begin{array}{l}-0.179 \pm 0.345 \\
0.66\end{array}$ \\
\hline $\begin{array}{l}\text { Mean post-load glucose } \\
(\mathrm{mmol} / \mathrm{l})\end{array}$ & $11.96 \pm 1.67$ & $11.95 \pm 1.79$ \\
\hline $\mathbf{K}(\% / \mathrm{min})$ & $1.58 \pm 0.50$ & $1.80 \pm 0.50$ \\
\hline Weight index & ${ }^{\mathrm{a}} 0.95 \pm 0.10$ & $1.04 \pm 0.13$ \\
\hline
\end{tabular}

Table 3. Comparison between subjects with low (quartile I) and high (quartile IV) HDL cholesterol

\begin{tabular}{|c|c|c|}
\hline \multirow[b]{3}{*}{ Fasting IRI (mU/l) } & \multicolumn{2}{|c|}{ HDL cholesterol } \\
\hline & \multicolumn{2}{|c|}{$\begin{array}{l}\text { Quartile I } \quad \text { Quartile IV } \\
(<1.02 \mathrm{mmol} / \mathrm{l})(>1.48 \mathrm{mmol} / \mathrm{l})\end{array}$} \\
\hline & ${ }^{\mathrm{b}} 16.6 \pm 11.0$ & $9.1 \pm 5.71$ \\
\hline $\begin{array}{l}\text { Mean IRI after IV glucose } \\
\quad(\mathrm{mU} / \mathrm{l})\end{array}$ & $b_{41.5} \pm 20.93$ & $27.1 \pm 14.41$ \\
\hline HDL triglycerides $(\mathrm{mmol} / \mathrm{l})$ & $0.13 \pm 0.07$ & $0.11 \pm 0.04$ \\
\hline $\begin{array}{l}\text { VLDL triglycerides }(\mathrm{log}) \\
(\text { antilog })(\mathrm{mmol} / 1)\end{array}$ & $\begin{array}{l}c^{0} 0.014 \pm 0.408 \\
1.03\end{array}$ & $\begin{array}{l}-0.458 \pm 0.349 \\
0.35\end{array}$ \\
\hline LDL cholesterol (mmol/l) & $3.02 \pm 0.61$ & $3.24 \pm 0.69$ \\
\hline $\mathrm{K}(\% / \mathrm{min})$ & $1.66 \pm 0.48$ & $1.55 \pm 0.43$ \\
\hline Weight index & ${ }^{\mathrm{a}} 1.03 \pm 0.10$ & $0.97 \pm 0.11$ \\
\hline
\end{tabular}

${ }^{\mathrm{a}} p<0.05 \quad{ }^{\mathrm{b}} p \leqslant 0.01 \quad{ }^{\mathrm{c}} p<0.001 . \mathrm{K}=$ disappearance rate of glucose $/ \mathrm{min}$

Table 4. The different variables for the 94 men studied (mean $\pm \mathrm{SD}$ )

\begin{tabular}{lcc}
\hline F asting IRI (mU/1) & 13 & \pm 8.6 \\
Mean IRI after IV glucose (mU/1) & 34 & \pm 18.5 \\
Serum cholesterol (mmol/1) & $5.41 \pm 1.05$ \\
Serum triglycerides (log) & $0.028 \pm 0.267$ \\
$\quad$ (antilog) (mmol/l) & 1.07 \\
HDL cholesterol (mmol/1) & $1.28 \pm 0.36$ \\
HDL triglycerides (mmol/1) & $0.12 \pm 0.06$ \\
LDL cholesterol (mmol/l) & $3.21 \pm 0.80$ \\
VLDL cholesterol (log) & $-0.394 \pm 0.325$ \\
$\quad$ (antilog) (mmol/1) & 0.40 \\
VLDL triglycerides (log) & $-0.226 \pm 0.369$ \\
$\quad$ (antilog) (mmol/1) & 0.59 \\
Fasting glucose (mmol/1) & $5.18 \pm 0.59$ \\
K (\%/min) & $1.74 \pm 0.62$ \\
Weight index & $1.0 \pm 0.11$ \\
\hline
\end{tabular}

$\mathrm{K}=$ disappearance rate of glucose $/ \mathrm{min}$ 
with high plasma insulin response have low HDL cholesterol levels. These results are in agreement with the observation by Enger and Erikssen [33] that high post glucose load plasma insulin was associated with low HDL cholesterol levels. However the mean body weight index of their subjects with high post glucose insulin levels was 1.10 and different from 0.96 for their subjects with low insulin response. The influence of obesity in their observations can therefore not be ruled out. In the present study, the men with high plasma insulin after glucose challenge have a mean body weight index of 1.04 which is $10 \%$ greater than the body weight index $(0.95)$ of the subjects with low plasma insulin levels. This represents a slight (4\%) excess above the mean body weight index (1.0) observed in the overall population (Table 4). The effect of a slight body weight excess cannot be ruled out but the association of high plasma insulin and low HDL cholesterol is not related to overt obesity. Similarly when the subjects are stratified according to their HDL cholesterol levels, low HDL cholesterol is associated with high fasting and post-load insulin levels and with a slight body weight excess without overt obesity.

HDL cholesterol is influenced by several factors such as alcohol intake, cigarette smoking and physical activity [35-39]. Lower HDL cholesterol among men with high plasma insulin when compared to men with low plasma insulin, was not related to differences in alcohol consumption, cigarette smoking or physical activity.

Glucose stimulates insulin secretion. The differences in plasma insulin concentrations between the men in the lowest and highest quartiles of plasma insulin could therefore be secondary to different blood glucose levels. This possibility was ruled out as the mean fasting glucose and the mean glucose after the IV load did not differ in subjects with high or low plasma insulin. The mean glucose disappearance rates were within the normal range and did not differ between subjects with high or low endogenous insulin and high or low HDL cholesterol.

There is an interdependence between plasma triglycerides and HDL metabolism [17, 40, 41]. The inverse relationship between HDL cholesterol and VLDL triglyceride levels is well documented $[2,42$, 43]. In the present study, the low HDL cholesterol of the subjects with high plasma insulin was not related to differences in VLDL triglyceride levels even though they did tend to have slightly higher VLDL triglyceride levels than men with low plasma insulin.

The increase of HDL triglyceride levels observed among the subjects with high insulin levels after the glucose load indicates that the HDL changes are not merely differences in cholesterol content but represent more profound alterations in the HDL composition. Similar changes have been described in patients with myocardial infarction [3, 44] and in diabetics [19].

The influence of insulin treatment on HDL has been shown in diabetes [23, 24]. From the present data it appears that even at physiological levels, plasma insulin and HDL cholesterol are closely related. It is indeed striking that factors which are associated with low plasma insulin and increased insulin sensitivity, such as physical activity and leanness $[37,38,45]$, tend also to increase HDL cholesterol. On the contrary, factors which decrease HDL cholesterol, such as physical inactivity and obesity, tend to be associated with high plasma insulin $[34,38,45]$. The present data suggest that the low HDL cholesterol in obesity and secondary to physical inactivity could be mediated through the endogenous insulin secretion.

It has been suggested that hyperinsulinism may play a role in the development of atherosclerosis [46-48] and may have a predictive value for the occurrence of coronary heart disease [49]. The association of high plasma insulin and low HDL cholesterol, a known coronary risk factor, needs to be investigated further particularly in relation to tissue and hepatic lipoprotein lipases [17, 40, 50-54].

Acknowledgements. Supported by a grant (3.843.077) of the Swiss National Science Foundation and a grant of the Sandoz Foundation. The authors wish to thank nurse Mrs Jaillot; B. Kalix, F. Ruinard, B. Von Arx and F. Ferracin for their exellent technical assistance and Miss B. Pfund for preparation of the manuscript.

\section{References}

1. Micheli H, Pometta D, Bloch A (1974) Cholestérol et triglycérides des lipoprotéines sériques isolées par ultracentrifugation. Relation avecl'athérosclérose coronarienne. Schweiz Med Wochensch 104: 1794-1796

2. Miller GJ, Miller NE (1975) Plasma-high-density-lipoprotein concentration and development of ischaemic heart disease. Lancet 1: 16-19

3. Pometta D, Micheli H (1979) Athérosclérose coronarienne et lipoprotéines sériques. Schweiz Med Wochenschr 109: 1926-1930

4. Pometta D, Micheli H, Jornot C, Scherrer JR (1978) HDL-cholestérol abaissé chez les proches parents et les malades victimes d'infarctus du myocarde. Schweiz Med Wochenschr 108: $1888-1891$

5. Rhoads GC, Gulbrandsen CL, Kagan A (1976) Serum lipoproteins and coronary heart disease. N Engl J Med 294: 293-298

6. Gordon T, Castelli WP, Hjortland MC, Kannel WB, Bawber TR (1977) High density lipoprotein as a protective factor against coronary heart disease. Am J Med 62:707-714

7. Logan RL, Riemersma RA, Thomson M, Oliver MF, Olsson AG, Walldius G, Rössner S, Kaijser L, Callmer E, Carlson LA, Lockerbie L, Lutz W (1978) Risk factors for ischaemic heartdisease in normal men aged 40. Edinburgh-Stockholm study. Lancet 1:949-955

8. Carew TE, Hayes SB, Koschinsky T, Steinberg D (1976) A mechanism by which high-density lipoproteins may slow the atherogenic process. Lancet 1:1315-1317

9. Reckless JPD, Weistein DB, Steinberg D (1978) Lipoprotein and cholesterol metabolism in rabbit arterial endothelial cells in culture. Biochim Biophys Acta 529: 475-487

10. Stein Y, Glangeaud MC, Fainaru M, Stein O (1975) The re- 
moval of cholesterol from aortic smooth muscle cells in culture and landschütz ascites cells by fractions of human high-density apolipoprotein. Biochim Biophys Acta 380: 106-118

11. Micheli H, Pometta D, Jornot C, Scherrer JR (1979) High density lipoprotein cholesterol in male relatives of patients with coronary heart disease. Atherosclerosis 32:269-276

12. Pometta D, Micheli H, Suenram A, Jornot C (1979) HDLlipids in close relatives of coronary heart disease patients. Environmental and genetic influences. Atherosclerosis 34: 419-429

13. Pometta D, Micheli H, Raymond L, Oberhaensli I, Suenram A (1980) Decreased HDL cholesterol in prepubertal and pubertal children of CHD patients. Atherosclerosis 36: 101-109

14. Righetti A, Scherrer JR, Micheli H, Pometta D (1973) Etude clinique des relations entre le diabète, les hyperlipoprotéinémies et l'athéromatose. Schwciz Med Wochenschr 103: 668-673

15. Kannel WB, Mc Gee DL (1979) Diabetes and cardiovascular risk factors: The Framingham study. Circulation 59: 8-13

16. Santen RJ, Willis PW, Fajan SS, Arbor A (1972) Atherosclerosis in diabetes mellitus - correlation with serum lipid levels, adiposity and serum insulin level. Arch Intern Med 130: 833 -843

17. Saudek CD, Eder HA (1979) Lipid metabolism in diabetes mellitus. Am J Med 66: 843-852

18. Keen H, Jarrett RJ, Alberti KGMM (1979) Diabetes mellitus: a new look at diagnostic criteria. Diabetologia 16: 283-285

19. Schonfeld G, Birge C, Miller JP, Kessler G, Santiago J (1974) Apolipoprotein $B$ levels and altered lipoprotein composition in diabetes. Diabetes 23:827-834

20. Lopes-Virella MFL, Stone PG, Colwell JA (1977) Serum high density lipoprotein in diabetic patients. Diabetologia 13: 285-291

21. Howard BV, Savage PJ, Bennion LJ, Benett PH(1978) Lipoprotein composition in diabetes mellitus. Atherosclerosis 30 : 153-162

22. Taskinen MR, Nikkilä EA (1979) Lipoprotein lipase activity of adipose tissue and skeletal muscle in insulin-deficient human diabetes. Diabetologia 17:351-356

23. Nikkilä EA, Hormila $\mathrm{P}(1978)$ Serum lipids and lipoproteins in insulin-treated diabetes. Demonstration of increased high density lipoprotein concentrations. Diabetes 27: 1078-1086

24. Calvert GD, Graham JJ, Mannik T, Wise PH, Yeates RA (1978) Effects of therapy on plasma-high-density-lipoprotein-cholestetol concentration in diabetes mellitus. Lancet 2: 66-68

25. Kennedy AL, Lappin TR, Lavery TD, Hadden DR, Weaver JA, Montgomery DA (1978) Relation of high-density lipoprotein cholesterol concentration to type of diabetes and its control. $\mathrm{Br}$ Med J 2: 1191-1194

26. Bisetti A (1980) Serum lipids and lipoproteins in diabetes mellitus. Département de Médecine, Université de Genève. Thèse no 3826 , Genève

27. Lewis B, Chait A, Sigurdsson G, Mancini M, Farinaro E, Oriente P, Carlson LA, Ericsson M, Micheli H, Pometta D (1978) Serum lipoproteins in four European communities: a quantitative comparison. Eur J Clin Invest 8: 165-173

28. Abell LL, Levy BB, Brodie BB, Kendall FE (1952) Simplified method for the estimation of total cholesterol in serum and demonstration of its specificity. J Biol Chem 195:357-366

29. Soloni FG (1971) Simplified manual micro-method for determination of serum triglycerides. Clin Chem 17:529-534

30. Schmidt FH (1971) Methoden der Harn- und Blutzuckerbestimmung. In: Pfeiffer EF (ed) Handbuch des diabetes mellitus, vol H. Lehmanns JF Verlag, München, pp 913-946

31. Wide L, Porath J (1966) Radioimmunoassay of proteins with the use of Sephadex-coupled antibodies. Biochim Biophys Acta 130: 257-260

32. Amatuzio DS, Stutzman FL, Vanderbilt MJ, Nesbitt S (1953) Interpretation of the rapid intravenous glucose tolerance test in normal individuals and in mild diabetes mellitus. $\mathrm{J}$ Clin Invest 32: 428

33. Enger SC, Erikssen J (1979) High density lipoproteins, insulin secretion and coronary risk factors in latent coronary insufficiency. Scand J Clin Lab Invest 39: 627-634
34. Bagdade JD, Bierman EL, Porte D Jr (1967) The significance of basal insulin levels in evaluation of the insulin response to glucose in diabetic and non-diabetic subjects. J Clin Invest 46: $1549-1557$

35. Castelli WP, Doyle JT, Gordon T, Hames CG, Hjortland MC, Hulley SB, Kagan A, Zukel WJ (1977) Alcohol and blood lipids. The cooperative lipoprotein phenotyping study. Lancet 2: $153-155$

36. Garrison RJ, Kannel WB, Feinleib M, Castelli WP, McNamara PM, Padgett SJ (1978) Cigarette smoking and HDL cholesterol. The Framingham offspring study. Atherosclerosis 30: 17-25

37. Nikkilä EA, Taskinen M-R, Rehunen S, Härkönen M (1978) Lipoprotein lipase activity in adipose tissue and skeletal muscle of runners: relation to serum lipoproteins. Metabolism 27: $1661-1671$

38. Streja D, Mymin D (1979) Moderate exercise and high-density lipoprotein-cholesterol, observations during a cardiac rehabilitation program. J Am Med Assoc 242: 2190-2192

39. Williams P, Robinson D, Bailey A (1979) High-density lipoprotein and coronary risk factors in normal men. Lancet 1: 72-75

40. Nikkilä EA (1978) Metabolic regulation of plasma high density lipoprotein concentrations. Eur J Clin Invest 8: 111-113

41. Tall AR, Small DM (1978) Plasma high-density lipoproteins. N Engl J Med 299: 1232-1236

42. Schaefer EJ, Levy RI, Anderson DW, Danner RN, Brewer HB Jr, Blackwelder WC (1978) Plasma-triglycerides in regulation of HDL-cholesterol levels. Lancet 2: 391-392

43. Wilson DE, Lees RS (1972) Metabolic relationships among the plasma lipoproteins. Reciprocal changes in the concentrations of very low and low density lipoproteins in man. J Clin Invest 51:1051-1057

44. Bergstrand R, Wiklund O, Holm G (1979) Glucose tolerance, plasma insulin and $\alpha$-lipoproteins in young male myocardial infarction patients compared with controls matched on serum cholesterol level. Eur J Clin Invest 9:381-384

45. Lohmann D, Liebold F, Heilmann W, Senger H, Pohl A (1978) Diminished insulin response in highly trained athletes. Metabolism 27: 521-524

46. Stout RW (1977) The realtionship of abnormal circulating insulin levels to atherosclerosis. Atherosclerosis 27:1-13

47. Stout RW (1979) Diabetes and atherosclerosis - The role of insulin. Diabetologia 16: 141-150

48. Duggan JM (1979) Ischaemic heart disease - an hypothesis to integrate the role of insulin, fibre and sucrose. Med Hypothesis 5:209-219

49. Pyörälä K (1979) Relationship of glucose tolerance and plasma insulin to the incidence of coronary heart disease: results from two population studies in Finland. Diabetes Care 2: 131-141

50. Glueck CJ (1975) Post-heparin lipoprotein lipases. N Engl J Med 292: 1347-1348

51. Kekki M (1980) Lipoprotein-lipase action determining plasma high density lipoprotein cholesterol level in adult normolipaemics. Atherosclerosis 37:143-150

52. Kuusi T, Saarinen P, Nikkilä EA (1980) Evidence for the role of hepatic endothelial lipase in the metabolism of plasma high density lipoprotein ${ }_{2}$ in man. Atherosclerosis 36: 589-593

53. Nikkilä EA, Taskinen M-R, Kekki M (1978) Relation of plasma high-density lipoprotein cholesterol to lipoprotein-lipase activity in adipose tissue and skeletal muscle of man. Atherosclerosis $29: 497-501$

54. Harno K, Nikkilä EA, Kuusi T (1980) Plasma HDL-cholesterol and postheparin plasma hepatic endothelial lipase (HL) activity: relationship to obesity and non-insulin dependant diabetes (NIDDM). Diabetologia 19:281

Received: 21 January 1981

and in revised form: 26 May 1981

Professor D. Pometta

Division de diabétologie

Hôpital Cantonal Universitaire

CH-1211 Geneva 4, Switzerland 